\title{
High expression of DNA methyltransferases in primary human medulloblastoma
}

\author{
Tímea Pócza ${ }^{1,2}$, Tibor Krenács ${ }^{3,4}$, Eszter Turányi ${ }^{3}$, János Csáthy ${ }^{1}$, Zsuzsanna Jakab $^{1}$, Peter Hauser ${ }^{1}$ \\ ${ }^{1} 2^{\text {nd }}$ Department of Pediatrics, Semmelweis University, Budapest, ${ }^{2}$ Department of Molecular Genetics, National Institute \\ of Oncology, Budapest, ${ }^{3}{ }^{\text {st }}$ Department of Pathology and Experimental Cancer Research, Semmelweis University, Budapest, \\ ${ }^{4}$ Tumor Progression Research Group, Joint Research Organization of the Hungarian Academy of Sciences and Semmelweis \\ University, Budapest, Hungary
}

\begin{abstract}
Epigenetic alterations have been implicated in cancer development. DNA methylation modulates gene expression, which is catalyzed by DNA methyltransferases (DNMTs). The objective of our study was to evaluate expression of DNMTs in medulloblastoma and analyze its correlation with clinical features. Nuclear expression of DNMT1, DNMT3A and DNMT3B was analyzed in human primary medulloblastoma of 44 patients using immunohistochemistry. Correlation of expression of DNMT levels with classical histological subtypes, novel molecular subgroups and survival of patients was analyzed. Elevated expression of DNMT1, DNMT3A and DNMT3B was observed in $63.64 \%$, $68.18 \%$ and $72.73 \%$ of all cases, respectively. None of them showed a correlation with classical histology or survival. Concerning molecular subtypes, significantly higher expression of DNMT1 was observed in the SHH group compared to non-SHH samples $(p=0.02)$, but without significant difference in DNMT3A or DNMT3B levels between any subtypes. In conclusion, DNMT1, DNMT3A and DNMT3B are highly expressed in human medulloblastoma samples, suggesting that promoter hypermethylation may play a role in medulloblastoma development. Demethylation of tumor suppressor gene promoters may be considered as a possible future target in therapy of medulloblastoma.
\end{abstract}

Key words: medulloblastoma, DNA methyltransferases, survival, SHH.

\section{Introduction}

Medulloblastoma (MB) is the most frequent malignant brain tumor in childhood, with various histological appearances. There are non-overlapping histological (classic, desmoplastic, extensive nodular, large cell/anaplastic) and molecular classifications (SHH, WNT, Group 3 and 4) for medulloblastoma $[3,6,11,23,25,27,34]$. Despite multimodal therapies, the $70-75 \%$ long-term survival rate has not been exceeded yet in high-risk patients [13,29,34]. A more precise classification of patients would help to develop a more effective treatment strategy and reduce side effects $[3,11,23]$.

There is emerging evidence that epigenetic changes contribute to carcinogenesis. The most important mechanisms of epigenetic alteration are DNA methylation, histone modification and microRNA regulation. DNA methyltransferases (DNMTs) are enzymes transferring methyl groups to cytosine in $\mathrm{CpG}$ dinu- 
cleotides, resulting in gene silencing. The DNMT family has three active members: DNMT1, DNMT3A and DNMT3B. DNMT3A and DNMT3B are regarded as de novo methyltransferases, whilst DNMT1 reacts on hemimethylated DNA, copying the methylation pattern during replication. Generally, tumor cells are characterized by global hypomethylation and hypermethylation of certain gene promoters. Therefore, repetitive elements are hypomethylated and specific tumor suppressor genes are repressed due to hypermethylation. These may contribute to chromosomal instability and abnormal gene silencing that could promote tumor-initializing steps [2,9,14,28,38]. Promoter hypermethylation of tumor suppressor genes and DNA repair genes has been observed in a wide variety of tumors, such as colorectal, breast cancer, glioma and medulloblastoma [19,22,36]. Overexpression of DNMTs was detected at the mRNA or protein level. Increased DNMT1 expression was described in gastric cancers, along with DNMT3A in breast and pancreatic cancer, or along with DNMT3B in glioma [8,16,30,38,39]. Although there is emerging evidence that epigenetic events play a remarkable role in the development of adult cancers, our knowledge about their role in pediatric brain tumors is still very limited.

DNA methylation studies in medulloblastoma have focused on the role of tumor suppressor genes in the development of brain tumors, and shed light on contradictory results in the majority of genes, except for RASSF1A [37]. Recent studies indicate that the DNA methylation profile can be used for MB subgrouping and disease risk assessment $[18,35]$.

The aims of our study are to characterize the expression of DNMTs in human medulloblastoma samples and their potential prognostic role in survival of patients. Possible correlations of DNMT proteins and clinicopathological features are also analyzed.

\section{Material and methods \\ Medulloblastoma tissue samples}

Formalin-fixed, paraffin-embedded MB tumor samples were collected from the National Institute of Neurosciences (Budapest, Hungary) and $1^{\text {st }}$ Institute of Pathology and Experimental Cancer Research, Semmelweis University (Budapest, Hungary). Forty-four primary medulloblastoma samples removed surgically between 2004 and 2010 and related clinical data of patients derived from the
Hungarian Pediatric Cancer Registry were used. The study was approved by the Ethics Committee of the Institutional Ethical Review Board of Semmelweis University (TUKEB No. 30/2015).

\section{Tissue microarray (TMA) construction and immunohistochemistry}

Hematoxylin and eosin (HE) stained sections were reviewed by a neuropathologist to select representative areas for producing TMA. TMA blocks were created by a computer-controlled TMA Master (3DHISTECH, Budapest, Hungary) instrument. Depending on sample quality one or two cores of representative areas with a diameter of $2 \mathrm{~mm}$ were taken from each tumor sample. From the TMA blocks $4 \mu \mathrm{m}$ sections were created. Sections were deparaffinized, rehydrated, and endogenous peroxidase activity was blocked. Heat-induced antigen retrieval was performed with Tris-EDTA buffer $(\mathrm{pH}=9.0)$ for $45 \mathrm{~min}$ in a microwave oven. Sections were incubated overnight using anti-DNMT1 antibody (dilution 1 : 200; Ab19905, Abcam, Cambridge, UK), anti-DNMT3A antibody (dilution 1 : 600; Ab13888, Abcam, Cambridge, UK) and anti-DNMT3B antibody (dilution 1 : 200; Ab13604, Abcam, Cambridge, UK) diluted in 5\% BSA containing Tris-buffered saline (TBS; $\mathrm{pH}=7.4$ ). Antigen development was performed by Novolink Polymer Detection System (Novocastra, Wetzlar, Germany) following the manufacturer's instructions. Reactions were visualized by 3,3'-diaminobenzidine (DAB) (DAKO, Denmark) as a substrate, and then slides were counterstained by hematoxylin. Tonsil for DNMT1, and kidney for DNMT3A and DNMT3B were used as positive tissue controls.

For determination of the WNT subgroup anti- $\beta$-catenin antibody (dilution 1 : 150; M-3539, DAKO, Denmark) and of the SHH subgroup antisecreted frizzled-related protein 1 (SFRP1) antibody (dilution 1 : 1500; ab-4193, Abcam, Cambridge, UK), characteristic proteins of these pathways, were applied. Immunohistochemical reactions were executed as described above, but antigen retrieval was performed in TE buffer boiled in a pressure cooker for 20 minutes.

\section{Evaluation of immunostaining}

Slides were digitalized by a Pannoramic Scan instrument and examined by Pannoramic Viewer 
software (3DHISTECH, Budapest, Hungary). To evaluate DNMT expression only nuclear staining was considered. Intensity of staining and rate of positive cells were calculated from 1,000 cells in a representative area of each sample. According to the intensity of staining, four values were created: 0 (negative), 1 (weak), 2 (moderate) and 3 (strong). The proportion of positive cells was ranked in five groups: 0 (negative), 1 (1-25\%), 2 (26-50\%), 3 (51-75\%) and 4 (76$100 \%)$. The products of the two values (0-12) were divided into two groups: $0-3$ regarded as no/weak expression and 4-12 regarded as moderate/strong expression. Samples were classified into WNT or SHH subgroups when the proportion of positive cells with nuclear $\beta$-catenin or negative nuclear $\beta$-catenin and positive SFRP1 staining was above $10 \%[7,27]$.

\section{Statistical analysis}

All statistical analysis was performed using Statistica software (StatSoft Inc., Tulsa, OK, USA). Survival of patients was calculated by the Kaplan-Meier method. Correlation of expression of DNMTs and survival was examined by the log-rank test. Correlation of expression of each DNMT was analyzed by the Spearman rank order test. Correlation of expression of DNMTs and age, gender, histological subtype or molecular subgroups was examined by the Mann-Whitney U-test and Fisher's exact test, when appropriate. Results were considered statistically significant when the $p$ value was less than 0.05 .

\section{Results}

\section{Patients' data}

Demographic characteristics of the studied cohort are summarized in Table I. Median age of 44 patients was 8.5 years (range $1.1-28.7$ years). The proportion of male patients was $55 \%$. Histologically, $84.1 \%, 11.4 \%$ and $4.5 \%$ of patients showed classic, desmoplastic and large cell/anaplastic (L/A) type of medulloblastoma, respectively. Survival data were available in 40 patients (90.9\%). Median follow-up time was 5.6 years (range 0-9.7 years). Patients were treated according to the Hungarian MBL2004/2008 schedules [15]. There is no standard treatment for adults with medulloblastoma in Hungary. Patients are treated according to the individual decision of each treating physician, and these treatment details are poorly accessible in Hungary. Therefore, adult patients were omitted from the survival analysis.

\section{Expression of DNMTs in human medulloblastoma}

Elevated (moderate/strong) expression of DNMT1, DNMT3A and DNMT3B was observed in 63.64\%, $68.18 \%$ and $72.73 \%$ of patients, respectively (Table I). Representative stains are shown in Figure 1. The relationship of histology and DNMT expression was evaluated only in the classic and desmoplastic type. Moderate/strong expression of DNMT1 was detected in $62.2 \%$ of classic and $60.0 \%$ of desmoplastic, of DNMT3A in $70.3 \%$ of classic and $60.0 \%$ of desmoplastic, and of DNMT3B in $70.3 \%$ of classic and $80.0 \%$ of desmoplastic samples. We could analyze only two samples of L/A subtype. Both of them showed moderate/strong expression for DNMT1 and DNMT3B, but only one for DNMT3A.

\section{Correlation between DNMT expression and patients' data}

There was no correlation between the expression of DNMT1, DNMT3A and DNMT3B and age at disease onset or gender or histological subtype (Table II). Kaplan-Meier curves, based on different expression of DNMTs, did not show a significant difference in overall survival (Fig. 2). None of the DNMTs could be used as a prognostic marker for medulloblastoma in our cohort. DNMT1 and DNMT3A $(p=0.08)$, or DNMT1 and DNMT3B $(p=0.17)$ or DNMT3A and DNMT3B $(p=0.69)$ did not show a co-expression pattern. Expression of nuclear $\beta$-catenin was shown only in one patient $(2.3 \%)$ with weak staining. There were 12 (27.3\%) patients belonging to $\mathrm{SHH}$ subgroup according to their cytoplasmic, membranous or secreted SFRP1 expression and lack of nuclear $\beta$-catenin (Table I). Expression of DNMT1 in the $\mathrm{SHH}$ subgroup compared to the non-WNT/non$\mathrm{SHH}$ subgroup of patients was significantly higher $(p=0.02)$, whereas expression of DNMT3A and DNMT3B did not differ significantly between different groups ( $p=0.78$ and $p=0.17$, respectively, Table II).

\section{Discussion}

In recent years a new prognostic classification of medulloblastoma was introduced by molecular findings, whilst there are still several twists in this classification system. It is still motivating to find further prognostic markers $[3,6,11,23,25,27,34]$. Nowadays, an exact diagnosis of pediatric brain tumors can be established based on the methylation profile of dif- 
Table I. Characteristics of patients and results of immunohistochemical staining of DNMTs, $\beta$-catenin, and SFRP1

\begin{tabular}{|c|c|c|c|c|c|c|c|c|c|c|}
\hline & Gender & Histology & $\begin{array}{l}\text { Age at disease } \\
\text { onset (years) }\end{array}$ & State & $\begin{array}{c}\text { Survival } \\
\text { (years) }\end{array}$ & DNMT1* & DNMT3A* & DNMT3B* & $\beta$-catenin & SFRP1 \\
\hline 1 & $\mathrm{~F}$ & Classic & 1.18 & Dead & 0.18 & 0 & 0 & 0 & Negative & Negative \\
\hline 2 & M & $\mathrm{L} / \mathrm{A}$ & 7.84 & Dead & 1.47 & 9 & 4 & 6 & Negative & Positive \\
\hline 3 & $\mathrm{~F}$ & Classic & 5.99 & Dead & 4.56 & 4 & 9 & 3 & Negative & Negative \\
\hline 4 & $\mathrm{~F}$ & Classic & 14.04 & Dead & 0.00 & 4 & 6 & 8 & Negative & Negative \\
\hline 5 & M & Classic & 10.81 & Dead & 7.98 & 4 & 8 & 8 & Negative & Positive \\
\hline 6 & $F$ & Classic & 3.31 & Alive & 9.38 & 6 & 8 & 12 & Negative & Negative \\
\hline 7 & M & Classic & 13.54 & Alive & 9.74 & 8 & 12 & 12 & Negative & Negative \\
\hline 8 & $M$ & Classic & 17.09 & Alive & 8.99 & 2 & 0 & 8 & Negative & Positive \\
\hline 9 & $\mathrm{~F}$ & Classic & 10.09 & Dead & 3.07 & 2 & 8 & 8 & Negative & Negative \\
\hline 10 & M & Desmoplastic & 14.54 & Alive & 9.08 & 1 & 2 & 3 & Negative & Negative \\
\hline 11 & $M$ & Desmoplastic & 5.14 & Dead & 0.59 & 4 & 4 & 6 & Negative & Negative \\
\hline 12 & $\mathrm{~F}$ & Classic & 17.90 & Dead & 5.02 & 4 & 2 & 8 & Negative & Negative \\
\hline 13 & M & Classic & 3.11 & Dead & 0.92 & 2 & 1 & 4 & Negative & Negative \\
\hline 14 & $\mathrm{~F}$ & Classic & 4.71 & Alive & 8.54 & 4 & 6 & 12 & Negative & Negative \\
\hline 15 & M & Classic & 15.30 & Alive & 7.80 & 2 & 4 & 2 & Positive & Negative \\
\hline 16 & $\mathrm{~F}$ & Classic & 8.48 & Alive & 7.24 & 12 & 2 & 2 & Negative & Negative \\
\hline 17 & $\mathrm{~F}$ & Classic & 14.28 & Alive & 8.09 & 4 & 8 & 8 & Negative & Negative \\
\hline 18 & M & Desmoplastic & 6.63 & Alive & 7.90 & 3 & 12 & 8 & Negative & Positive \\
\hline 19 & $M$ & L/A & 13.84 & Dead & 1.94 & 4 & 3 & 12 & Negative & Positive \\
\hline 20 & M & Desmoplastic & 4.34 & Dead & 0.09 & 9 & 12 & 4 & Negative & Negative \\
\hline 21 & M & Classic & 8.56 & Alive & 7.00 & 2 & 4 & 12 & Negative & Negative \\
\hline 22 & M & Classic & 15.46 & Alive & 6.52 & 2 & 8 & 12 & Negative & Negative \\
\hline 23 & $M$ & Desmoplastic & 2.59 & Alive & 6.52 & 4 & 2 & 4 & Negative & Positive \\
\hline 24 & M & Classic & 4.50 & Dead & 1.92 & 4 & 12 & 3 & Negative & Negative \\
\hline 25 & $\mathrm{~F}$ & Classic & 9.30 & Dead & 5.54 & 8 & 12 & 12 & Negative & Negative \\
\hline 26 & M & Classic & 6.81 & Alive & 6.63 & 4 & 2 & 3 & Negative & Negative \\
\hline 27 & $\mathrm{~F}$ & Classic & 8.50 & Alive & 6.07 & 8 & 0 & 12 & Negative & Negative \\
\hline 28 & $M$ & Classic & 7.70 & Alive & 6.02 & 2 & 8 & 8 & Negative & Negative \\
\hline 29 & $\mathrm{~F}$ & Classic & 1.77 & Alive & 6.76 & 9 & 8 & 8 & Negative & Positive \\
\hline 30 & $\mathrm{~F}$ & Classic & 4.92 & Alive & 6.56 & 6 & 8 & 6 & Negative & Negative \\
\hline 31 & $M$ & Classic & 22.90 & NA & NA & 6 & 4 & 8 & Negative & Positive \\
\hline 32 & M & Classic & 10.76 & Dead & 5.22 & 2 & 2 & 4 & Negative & Negative \\
\hline 33 & $\mathrm{~F}$ & Classic & 21.43 & NA & NA & 6 & 0 & 12 & Negative & Positive \\
\hline 34 & $\mathrm{~F}$ & Classic & 16.71 & Alive & 5.67 & 2 & 12 & 1 & Negative & Negative \\
\hline 35 & M & Classic & 7.92 & Alive & 5.48 & 1 & 1 & 4 & Negative & Negative \\
\hline 36 & $\mathrm{~F}$ & Classic & 10.75 & Alive & 5.65 & 4 & 4 & 3 & Negative & Negative \\
\hline 37 & $\mathrm{~F}$ & Classic & 1.78 & Dead & 0.48 & 2 & 8 & 6 & Negative & Negative \\
\hline 38 & M & Classic & 4.63 & Alive & 4.99 & 4 & 3 & 4 & Negative & Negative \\
\hline 39 & M & Classic & 28.25 & NA & NA & 9 & 4 & 6 & Negative & Positive \\
\hline 40 & $\mathrm{~F}$ & Classic & 1.07 & Alive & 3.23 & 6 & 12 & 3 & Negative & Negative \\
\hline 41 & $\mathrm{~F}$ & Classic & 2.84 & Alive & 3.12 & 2 & 8 & 2 & Negative & Negative \\
\hline 42 & M & Classic & 13.18 & Alive & 2.80 & 2 & 8 & 8 & Negative & Negative \\
\hline 43 & $\mathrm{~F}$ & Classic & 28.69 & NA & NA & 9 & 12 & 2 & Negative & Positive \\
\hline 44 & M & Classic & 9.68 & Alive & 2.12 & 9 & 12 & 12 & Negative & Positive \\
\hline
\end{tabular}

*Product of intensity (0-3) and rate of positive cells (0-4), maximal value: 12 SFRP1 - secreted frizzled-related protein 1, DNMT - DNA methyltransferase, $M$ - male, $F$-female, L/A - large cell/anaplastic, NA - not available 

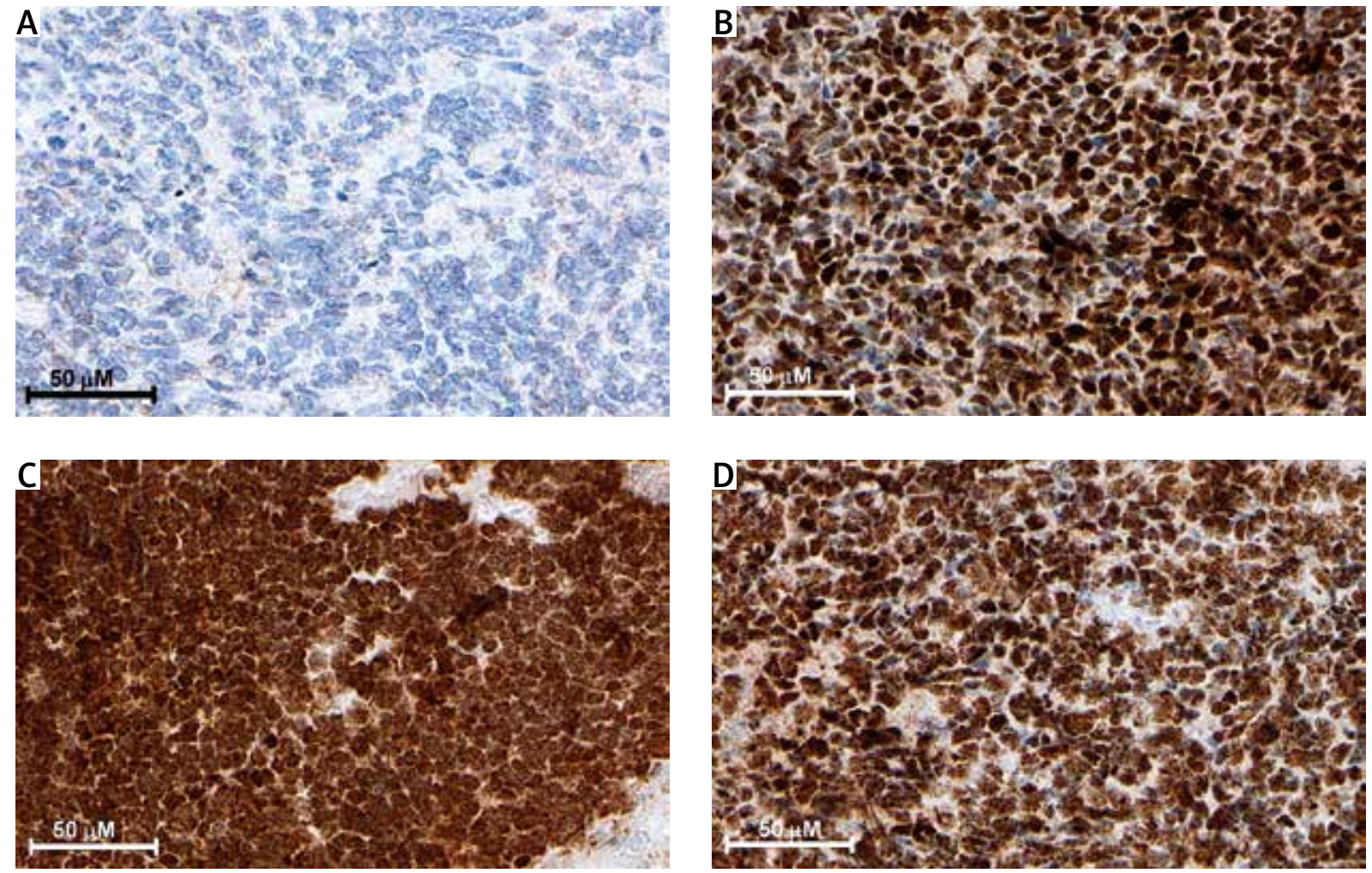

Fig. 1. Representative immunohistochemical staining of DNMTs in medulloblastoma. A) Negative staining of DNMT3A. B, C, D) Moderate/strong immunopositivity of DNMT1, DNMT3A and DNMT3B, respectively.

Table II. Evaluation of patients' characteristics and expression of different DNMTs. Correlation of DNMTs and clinical features are shown by probability value $(p)$

\begin{tabular}{|c|c|c|c|c|c|c|c|c|c|c|}
\hline & \multirow[t]{2}{*}{ All } & \multicolumn{2}{|c|}{ DNMT1 } & \multirow[t]{2}{*}{$p$} & \multicolumn{2}{|c|}{ DNMT3A } & \multirow[t]{2}{*}{$p$} & \multicolumn{2}{|c|}{ DNMT3B } & \multirow[t]{2}{*}{$p$} \\
\hline & & $\begin{array}{l}\text { No/ } \\
\text { Weak }\end{array}$ & $\begin{array}{l}\text { Moderate/ } \\
\text { Strong }\end{array}$ & & $\begin{array}{c}\text { No/ } \\
\text { Weak }\end{array}$ & $\begin{array}{l}\text { Moderate/ } \\
\text { Strong }\end{array}$ & & $\begin{array}{l}\text { No/ } \\
\text { Weak }\end{array}$ & $\begin{array}{l}\text { Moderate/ } \\
\text { Strong }\end{array}$ & \\
\hline Number of patients & 44 & $\begin{array}{c}16 \\
(36.36 \%)\end{array}$ & $\begin{array}{c}28 \\
(63.64 \%)\end{array}$ & \multirow{2}{*}{$0.91^{a}$} & $\begin{array}{c}14 \\
(31.82 \%)\end{array}$ & $\begin{array}{c}30 \\
(68.18 \%)\end{array}$ & \multirow{2}{*}{$0.91^{a}$} & $\begin{array}{c}12 \\
(27.27 \%)\end{array}$ & $\begin{array}{c}32 \\
(72.73 \%)\end{array}$ & \multirow{2}{*}{$0.65^{\circ}$} \\
\hline $\begin{array}{l}\text { Median age } \\
\text { of patients (years) }\end{array}$ & 8.53 & 9.33 & 8.49 & & 8.49 & 8.93 & & 7.65 & 8.93 & \\
\hline \multicolumn{11}{|l|}{ Gender } \\
\hline Male & 24 & 11 & 13 & \multirow{2}{*}{$0.21^{b}$} & 9 & 15 & \multirow{2}{*}{$0.52^{b}$} & 4 & 20 & \multirow{2}{*}{$0.10^{b}$} \\
\hline Female & 20 & 5 & 15 & & 5 & 15 & & 8 & 12 & \\
\hline \multicolumn{11}{|l|}{ Histological subtype } \\
\hline Classic & 37 & 14 & 23 & \multirow{2}{*}{$1.00^{\mathrm{b}}$} & 11 & 26 & \multirow{2}{*}{$0.64^{b}$} & 11 & 26 & \multirow{2}{*}{$1.00^{\mathrm{b}}$} \\
\hline Desmoplastic & 5 & 2 & 3 & & 2 & 3 & & 1 & 4 & \\
\hline Large cell/anaplastic & 2 & 0 & 2 & $\#$ & 1 & 1 & $\#$ & 0 & 2 & $\#$ \\
\hline \multicolumn{11}{|l|}{ Molecular subtype } \\
\hline Wnt & 1 & 1 & 0 & \# & 0 & 1 & \# & 1 & 0 & $\#$ \\
\hline Shh & 12 & 2 & 10 & \multirow{2}{*}{$0.02^{\mathrm{a} *}$} & 4 & 8 & \multirow{2}{*}{$0.78^{a}$} & 1 & 11 & \multirow{2}{*}{$0.17^{\circ}$} \\
\hline Non-Wnt/non-Shh & 21 & 13 & 18 & & 10 & 21 & & 10 & 21 & \\
\hline
\end{tabular}

aMann-Whitney U-test, ${ }^{b}$ Fisher's exact test, two-tailed, ${ }^{*}$ - not applicable, * - statistically significant 

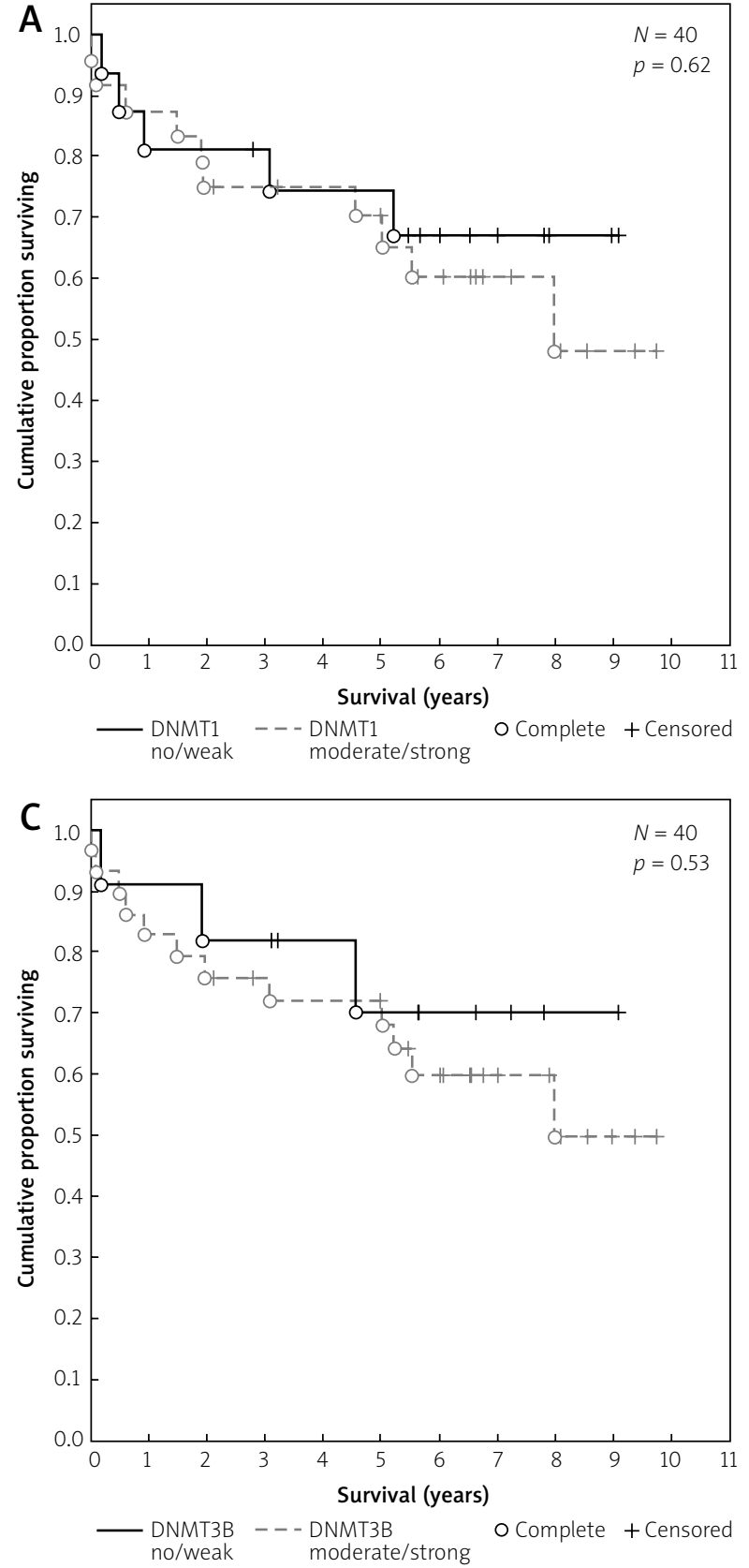

ferent tumor types [18,21,35]. DNMTs are responsible for DNA methylation, an important epigenetic regulation process, which contributes to development of cancer. DNMT1 is responsible for maintenance of methylation patterns during DNA replication. DNMT3A and DNMT3B are regarded as de novo methyl-transferases and abundantly expressed during embryonic development $[2,9,14,19,22,28,38]$.

In our study, expression of three members of the DNMT family (DNMT1, DNMT3A, DNMT3B) in me-

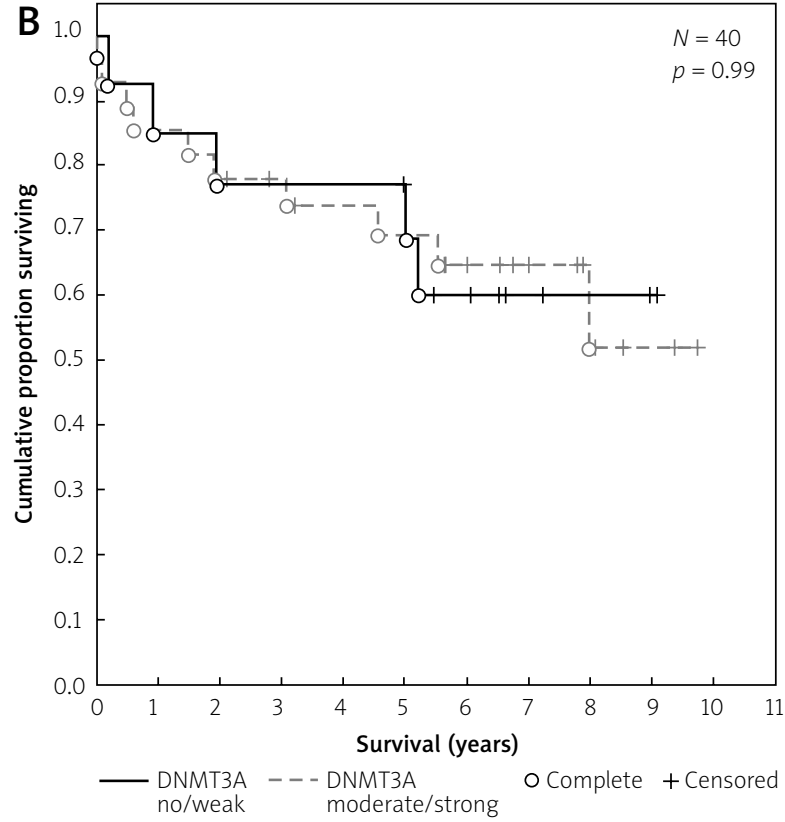

Fig. 2. Kaplan-Meier survival curves for DNMT1 (A), DNMT3A (B) and DNMT3B (C) expression. Presence of DNMTs did not influence survival in our patient cohort (without adult patients).

dulloblastoma samples and their possible effect on disease outcome were examined. During the development and progression of $\mathrm{MB}$, the biological role of DNMTs, crucial regulators of the methylation pattern, is not completely understood yet. In our study, the correlation of expression of these enzymes at the protein level and clinical data of MB patients were investigated.

In our experiments elevated expression of all DNMTs was observed in most of the MB samples. 
Correlation of expression of DNMTs and histological subtype of $M B$, age at disease onset or gender was not proven in our experience. Increased DNMT1 expression indicates worse outcomes in several types of cancers, such as gastric cancer, hepatocellular carcinomas and pancreatic ductal adenocarcinoma $[10,26,33]$. In contrast, our analysis showed no difference in disease outcome when comparing patients with no/weak and moderate/strong expression of three DNMTs, so DNMTs are not predictive markers for medulloblastoma survival. The different result may be due to the different biological nature of medulloblastoma and above-mentioned tumor types. While there are some common dysregulated signaling pathways (WNT, SHH, Notch) in medulloblastoma and in these other cancer types, differences could also be observed in regulation of the following pathways: in gastric cancer altered EGFR, ErbB, mTOR, VEGF, HGF/MET pathways, etc.; in hepatocellular carcinoma altered Ras/Raf/MAPK, mTOR, etc.; and in pancreatic ductal adenocarcinoma FGF, Notch, TGF- $\beta$, EGF and retinoid signaling $[1,31,32]$.

The SHH subgroup of MB is characterized by the expression of SFRP1 and lack of nuclear $\beta$-catenin $[17,27]$. Our results indicate that SHH pathway activation is associated with elevated DNMT1 expression, which could be a consequence of upregulation of DNMT1 by SHH in SHH-associated medulloblastomas. Similar observations were made in pancreatic cancer and in myelodysplastic syndrome (MDS) $[16,40]$. DNMT1 and DNMT3A could be regulated by Gli1, an effector of the SHH signaling pathway. The SHH pathway was inhibited in pancreatic cancer and MDS cell lines, resulting in decreased DNMT1 expression, whereas induction of the SHH pathway resulted in higher DNMT1 expression $[16,40]$. In contrast, DNMT1 inhibition resulted in increased expression of SFRP1 in MB cell lines [20]. One explanation could be that investigated MB cell lines do not belong to the SHH subgroup, since they showed lower levels of SFRP1 compared to the $\mathrm{SHH}$ subgroup. Among non-WNT/non-SHH patients, other mechanisms could result in DNMT1 activation. Further studies are needed to clarify the relationship between regulation of DNA methylation and SHH signaling pathway.

Theoretically, inhibition of DNA methylation is a therapeutic opportunity by reversing gene silencing $[9,12,14,38]$. An in vitro experiment showed that the DNMT inhibitor 5-aza-2'-deoxycytidine (decit- abine) reactivates the tumor suppressor PTCH1 gene in the MB cell line [4]. A combination of DNMT and histone deacetylase (HDAC) inhibitors was effective to prevent MB development in Ptch knockout mice, while in advanced stage tumors this therapy was less efficient [5]. Epigenetic modulators combined with multi-kinase inhibitor could enhance apoptosis in vitro in medulloblastoma cells [24].

In conclusion, this is the first study to analyze DNMT expression in medulloblastoma in terms of expression level and correlation with clinical data. Elevated expression of DNMTs in human medulloblastoma, and association of DNMT1 and SHH subgroups were observed, without an effect on survival. Based on increased expression of DNMTs in medulloblastoma, their inhibition has potential for further investigation to optimize therapy of medulloblastoma.

\section{Acknowledgments}

We thank Edit Parsch and Zita Bratu for excellent technical assistance, Miklós Garami for assistance in performing experiments and Balázs Hauser for help in preparation of the manuscript.

\section{Disclosure}

Authors report no conflict of interest.

\section{References}

1. Chen C, Wang G. Mechanisms of hepatocellular carcinoma and challenges and opportunities for molecular targeted therapy. World J Hepatol 2015; 7: 1964-1970.

2. Choi JD, Lee JS. Interplay between epigenetics and genetics in Cancer. Genomics Inform 2013; 11: 164-173.

3. DeSouza RM, Jones BR, Lowis SP, Kurian KM. Pediatric medulloblastoma - update on molecular classification driving targeted therapies. Front Oncol 2014; 4: 176.

4. Diede SJ, Guenthoer J, Geng LN, Mahoney SE, Marotta M, Olson JM, Tanaka H, Tapscott SJ. DNA methylation of developmental genes in pediatric medulloblastomas identified by denaturation analysis of methylation differences. Proc Natl Acad Sci U S A 2010; 107: 234-239.

5. Ecke I, Petry F, Rosenberger A, Tauber S, Mönkemeyer S, Hess I, Dullin C, Kimmina S, Pirngruber J, Johnsen SA, Uhmann A, Nitzki F, Wojnowski L, Schulz-Schaeffer W, Witt O, Hahn H. Antitumor effects of a combined 5-aza-2'deoxycytidine and valproic acid treatment on rhabdomyosarcoma and medulloblastoma in Ptch mutant mice. Cancer Res 2009; 69: 887-895.

6. Ellison DW. Childhood medulloblastoma: novel approaches to the classification of a heterogeneous disease. Acta Neuropathol 2010; 120: 305-316. 
7. Ellison DW, Dalton J, Kocak M, Nicholson SL, Fraga C, Neale G, Kenney AM, Brat DJ, Perry A, Yong WH, Taylor RE, Bailey S, Clifford SC, Gilbertson RJ. Medulloblastoma: clinicopathological correlates of SHH, WNT, and non-SHH/WNT molecular subgroups. Acta Neuropathol 2011; 121: 381-396.

8. Etoh T, Kanai Y, Ushijima S, Nakagawa T, Nakanishi Y, Sasako M, Kitano S, Hirohashi S. Increased DNA methyltransferase 1 DNMT1; protein expression correlates significantly with poorer tumor differentiation and frequent DNA hypermethylation of multiple CpG islands in gastric cancers. Am J Pathol 2004; 164: 689-699.

9. Gal-Yam EN, Saito Y, Egger G, Jones PA. Cancer epigenetics: modifications, screening, and therapy. Annu Rev Med 2008; 59 : 267-280.

10. Gao J, Wang L, Xu J, Zheng J, Man X, Wu H, Jin J, Wang K, Xiao H, Li S, Li Z. Aberrant DNA methyltransferase expression in pancreatic ductal adenocarcinoma development and progression. J Exp Clin Cancer Res 2013; 32: 86.

11. Gerber NU, Mynarek M, von Hoff K, Friedrich C, Resch A, Rutkowski S. Recent developments and current concepts in medulloblastoma. Cancer Treat Rev 2014; 40: 356-365.

12. Goffin J, Eisenhauer E. DNA methyltransferase inhibitors-state of the art. Ann Oncol 2002; 13: 1699-1716.

13. Gottardo NG, Gajjar A. Chemotherapy for malignant brain tumors of childhood. J Child Neurol 2008; 23: 1149-1159.

14. Gros C, Fahy J, Halby L, Dufau I, Erdmann A, Gregoire JM, Ausseil F, Vispé S, Arimondo PB. DNA methylation inhibitors in can cer: recent and future approaches. Biochimie 2012; 94: 2280 2296.

15. Hauser P, Jakab Z, Kiss C, Szegedi I, Bárdi E, Batyik K, Ottóffy G, Kajtár P, Szűcs R, Nagy K, Cservák J, Masát P, Bálint K, Kordás M, Bognár L, Kocsis B, Vízkeleti J, Kriván G, Kállay K, Benyó G, Schuler D, Garami M. Előzetes eredmények a medulloblastoma/prim itív neuroektodermális tumor PNET; kezelésében a magyar MBL 2004 kezelési sémával. Magyar Belorvosi Archívum 2009; 62: 196-201.

16. He S, Wang F, Yang L, Guo C, Wan R, Ke A, Xu L, Hu G, Xu X, Shen J, Wang X. Expression of DNMT1 and DNMT3a are regulated by GLI1 in human pancreatic cancer. PLoS One 2011; 6: e27684.

17. He J, Sheng T, Stelter AA, Li C, Zhang X, Sinha M, Luxon BA, Xie J. Suppressing Wnt signaling by the hedgehog pathway through sFRP-1. J Biol Chem 2006; 281: 35598-35602.

18. Hovestadt V, Remke M, Kool M, Pietsch T, Northcott PA, Fischer R, Cavalli FM, Ramaswamy V, Zapatka M, Reifenberger G, Rutkowski S, Schick M, Bewerunge-Hudler M, Korshunov A, Lichter P, Taylor MD, Pfister SM, Jones DT. Robust molecular subgrouping and copy-number profiling of medulloblastoma from smal amounts of archival tumour material using high-density DNA methylation arrays. Acta Neuropathol 2013; 125: 913-916.

19. Jin B, Robertson KD. DNA methyltransferases, DNA damage repair, and cancer. Adv Exp Med Biol 2013; 754: 3-29.

20. Kongkham PN, Northcott PA, Croul SE, Smith CA, Taylor MD, Rutka JT. The SFRP family of WNT inhibitors function as novel tumor suppressor genes epigenetically silenced in medulloblastoma. Oncogene 2010; 29: 3017-3024.

21. Korshunov A, Ryzhova M, Hovestadt V, Bender S, Sturm D, Capper D, Meyer J, Schrimpf D, Kool M, Northcott PA, Zheludkova O,
Milde T, Witt O, Kulozik AE, Reifenberger G, Jabado N, Perry A, Lichter P, von Deimling A, Pfister SM, Jones DT. Integrated analysis of pediatric glioblastoma reveals a subset of biologically favorable tumors with associated molecular prognostic markers. Acta Neuropathol 2015; 129: 669-678.

22. Lahtz C, Pfeifer GP. Epigenetic changes of DNA repair genes in cancer. J Mol Cell Biol 2011; 3: 51-58.

23. Li KK, Lau KM, Ng HK. Signaling pathway and molecular subgroups of medulloblastoma. Int J Clin Exp Pathol 2013; 6: 12111222.

24. Marino AM, FrijhoffJ, Calero R, Baryawno N, Ostman A, Johnsen JI. Effects of epigenetic modificators in combination with small molecule inhibitors of receptor tyrosine kinases on medulloblastoma growth. Biochem Biophys Res Commun 2014; 450: 1600-1605.

25. Massimino M, Giangaspero F, Garrè ML, Gandola L, Poggi G, Biassoni V, Gatta G, Rutkowski S. Childhood medulloblastoma. Crit Rev Oncol Hematol 2011; 79: 65-83.

26. Mutze K, Langer R, Schumacher F, Becker K, Ott K, Novotny A, Hapfelmeier A, Höfler H, Keller G. DNA methyltransferase 1 as a predictive biomarker and potential therapeutic target for chemotherapy in gastric cancer. Eur J Cancer 2011; 47: 1817-1825.

27. Northcott PA, Korshunov A, Witt H, Hielscher T, Eberhart CG, Mack S, Bouffet E, Clifford SC, Hawkins CE, French P, Rutka JT, Pfister S, Taylor MD. Medulloblastoma comprises four distinct molecular variants. J Clin Oncol 2011; 29: 1408-1414.

28. Okano M, Bell DW, Haber DA, Li E. DNA methyltransferases Dnmt3a and Dnmt3b are essential for de novo methylation and mammalian development. Cell 1999; 99: 247-257.

29. Packer RJ, Zhou T, Holmes E, Vezina G, Gajjar A. Survival and secondary tumors in children with medulloblastoma receiving radiotherapy and adjuvant chemotherapy: results of Children's Oncology Group trial A9961. Neuro Oncol 2013; 15: 97-103.

30. Rajendran G, Shanmuganandam K, Bendre A, Muzumdar D, Mujumdar D, Goel A, Shiras A. Epigenetic regulation of DNA methyltransferases: DNMT1 and DNMT3B in gliomas. J Neurooncol 2011; 104: 483-494.

31. Rhim AD, Stanger BZ. Molecular biology of pancreatic ductal adenocarcinoma progression: aberrant activation of developmental pathways. Prog Mol Biol Transl Sci 2010; 97: 41-78.

32. Riquelme I, Saavedra K, Espinoza JA, Weber H, García P, Nervi B, Garrido M, Corvalán AH, Roa JC, Bizama C. Molecular classification of gastric cancer: towards a pathway driven targeted therapy. Oncotarget 2015; 6: 24750-24779.

33. Saito Y, Kanai Y, Nakagawa T, Sakamoto M, Saito H, Ishii H, Hirohashi S. Increased protein expression of DNA methyltransferase DNMT 1 is significantly correlated with the malignant potential and poor prognosis of human hepatocellular carcinomas. Int J Cancer 2003; 105: 527-532.

34. Schroeder K, Gururangan S. Molecular variants and mutations in medulloblastoma. Pharmgenomics Pers Med 2014; 7: 43-51.

35. Schwalbe EC, Williamson D, Lindsey JC, Hamilton D, Ryan SL, Megahed H, Garami M, Hauser P, Dembowska-Baginska B, Perek D, Northcott PA, Taylor MD, Taylor RE, Ellison DW, Bailey S, Clifford SC. DNA methylation profiling of medulloblastoma allows robust subclassification and improved outcome predic- 
tion using formalin-fixed biopsies. Acta Neuropathol 2013; 125:

359-371.

36. Sciuscio D, Hegi ME. Epigenetics and Brain Cancer. In: Emerg ing Concepts in Neuro-Oncology. Watts C (ed.). Springer-Verlag, London 2013; pp. 21-40.

37. Sexton-Oates A, MacGregor D, Dodgshun A, Saffery R. The potential for epigenetic analysis of paediatric CNS tumours to improve diagnosis, treatment and prognosis. Ann Oncol 2015; 26: 1314-1324.

38. Subramaniam D, Thombre R, Dhar A, Anant S. DNA methyltransferases: a novel target for prevention and therapy. Front Oncol 2014; 4: 80.

39. Yu Z, Xiao Q, Zhao L, Ren J, Bai X, Sun M, Wu H, Liu X, Song Z, Yan Y, Mi X, Wang E, Jin F, Wei M. DNA methyltransferase 1/3a overexpression in sporadic breast cancer is associated with reduced expression of estrogen receptor-alpha/breast cancer susceptibility gene 1 and poor prognosis. Mol Carcinog 2015; 54: 707-719.

40. Zou J, Hong Y, Tong Y, Wei J, Qin Y, Shao S, Wang C, Zhou K. Sonic hedgehog produced by bone marrow-derived mesenchymal stromal cells supports cell survival in myelodysplastic syndrome. Stem Cells Int 2015; 2015: 957502. 